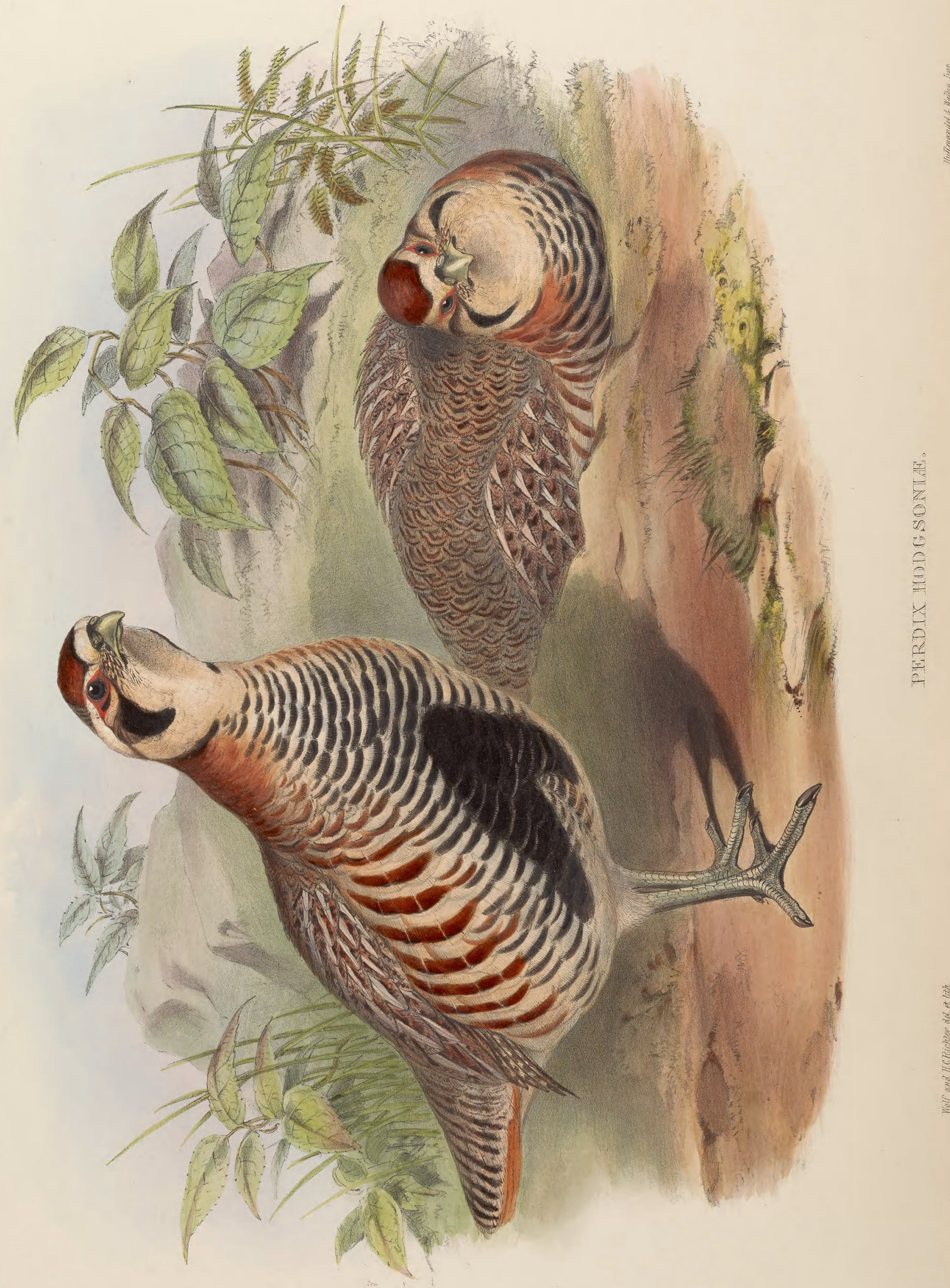




\title{
PERDIX HODGSONIA.
}

\author{
Thibet Partridge.
}

Sacfa Hodgsonia, Hodgs. Journ. Asiat. Soc. Beng., new ser. vol. xxv. p. 165. pl. not numbered.

THE Red-legged Partridges having been generically separated from our well-known Grey Partridge (Perdix cinerea), the latter bird has until now been the only species of the genus known; the discovery, then, of a second, in the distant and little-explored country of Thibet, will be regarded by ornithologists with especial interest, and it is with great pleasure that I give a representation of it in the "Birds of Asia."

For the knowledge of the existence of this fine bird I am indebted to two gentlemen, one-B. H. Hodgson, Esq.- celebrated for his high scientific attainments, and for the extent to which he has made us acquainted with the natural history of Nepaul; and the other-Lieut. William J. Smith, of the 75th Regt.-for his travels and shooting excursions on the high ranges or watershed of North-western India. To the latter gentleman the credit is due, I believe, of having brought the first specimen to Europe, while Mr. Hodgson has the merit of priority in naming and publishing a description of the species. A drawing from Mr. Hodgson, and a unique specimen on loan from Lieut. Smith, reached me almost simultaneously, and I here beg to record my sense of their kindness.

The colouring of the specimen was considerably paler than the drawing; this was doubtless due to the circumstance of its having been killed in the height of the breeding season, when, as is well known, the feathers become worn and, from long exposure, paler in colour. Mr. Hodgson states that his description was taken from a female. Lieut. Smith's bird is now deposited in the British Museum, where in all probability Mr. Hodgson's specimen will also find a resting-place, since it is there that the 10,000 specimens and drawings, so liberally presented by him to the country, are deposited. If hereafter it should be found that the bird represented in the drawing is distinct from that brought by Lieut. Smith, which, however, I think will not prove to be the case, I shall have much pleasure in giving it a place in this work. Mr. Hodgson has made this species the type of a new genus, to which he has given the appellation of Sacfa; but upon comparing Lieut. Smith's bird with a male of our well-known Partridge, I can come to no other conclusion than that it is of precisely the same form ; like that species, it presents no indication of a spur on the tarsus, while the horse-shoe-shaped mark on the breast, and other markings, are of a similar, but more decided character; the generic name of Sacpha must therefore, I fear, sink into a synonym. Mr. Hodgson states that it is called Sacfa or Sakpha by the natives; but Lieut. Smith tells me that the Chikore, a Red-legged Partridge (Caccabis Chular), is also called Sakpha; I therefore conclude that it is a term applied to Partridges generally.

In his account of this species, published in the twenty-fifth volume of the Journal of the Asiatic Society of Bengal, Mr. Hodgson says :-

"To General Jung Bahadoor, Prime Minister of Nepal, I am indebted for the gift of, what appears to me, decidedly a new species, and probably also a new type of the Partridge group of birds. The General, in his recent military expedition into Thibet, procured the bird alive; but it died at Kathmandu, and he sent me the spoils in very fine condition.

"I have taken the liberty of dedicating this handsome species to Mrs. Hodgson, whose accurate and tasteful delineations of Himalayan scenery will do much to attract attention to this fine field of scientific research.

"This fine species is denominated Salpha by the Thibetans. It was obtained in the western province of Tsang. I know nothing of its habits. My sample is a female, and therefore the peculiar heary overlying upper mandible, so marked in this sex, must be more so in the male, and resembles in fact that organ in Lophophorus, or the Monâl.

"The colours are as follows:-

"Bill and legs horn-green; orbital skin reddish, above transversely marked with black, rufous and chestnut, in frequent bars, the black being more developed on the wings, and the chestnut on the flanks, where indeed the black nearly disappears, while on the belly it is so much developed as to constitute the main and almost only colour. Neck, above and laterally, and all the lateral tail-feathers, full unmarked chestnut; cheeks, throat and breast luteous or albescent-buff; a black zone round the throat from the cap, and a black patch before the eye.

"In conclusion I may remark, that the bird has much of the character of Caccabis, whilst in colours it greatly resembles the Grey Partridge of India, without, however, losing certain Caccabine traits which the expert will at once detect."

To this statement Mr. Blyth appends the remark, "It most nearly approximates in type to Perdix cinerea ;" and I might ask, is not the overlapping of the bill, so strongly pointed out by Mr. Hodgson, due to the 
bird having been kept in confinement, for this character was not particularly conspicuous in the specimen I have figured from?

"I shot this fine bird," says Lieut. Smith, "near the Pangong Lake in Little Thibet. It is a male, and the only one of the species I have ever met with; therefore I can tell you but little of its habits. I found it with its covey of young ones, which were just out of the shells. Some of the latter hid themselves under the rock on which I was sitting, and the old bird came near enough to be killed with a stick. It made a great noise, ran remarkably fast, and did not take wing until very hard pressed. The hills in the neighbourhood of which it was discovered, were of a rugged and barren character, and destitute of forests or brushwood for about a hundred miles. I noticed that the hen bird was grey, but did not shoot her on account of the young ones.

"I shot my bird about one hundred miles north-east of the capital of Ladâk, in a part of the country which is very thinly inhabited. I had never heard of its existence before, and the Thibetans with me seemed as much surprised on seeing the bird as myself.

"This new species must be very scarce, for although I had been twice previously on shooting excursions in the same country, I did not meet with it on either occasion; and although on the present I remained for six weeks in the vicinity, I did not even see a second example; I regret therefore that I did not also secure the female."

Band across the forehead, stripe over each eye to the nape, sides of the neck and throat buffy-white; the band on the forehead bounded before and behind with a narrow line of black; feathers of the lores and ear-coverts buffy-white bordered with black; eyelash and a bare space behind the eye red, below the latter a broad semi-crescentic mark of black; crown of the head dark rust-red; occiput and nape mottled-buff and dark brown; back and sides of the neck rust-red, separated from the white of the throat by a line of black; feathers of the upper surface alternately barred with buff and reddish-brown; wing-coverts similar, but the bands not so regular, and with a stripe of light buff in the direction of the shaft; wing-feathers brown, crossed by irregular bars of buff; central tail-feathers pale greyish-buff, crossed by irregular bands of brown, and the grey portion freckled with brown; lateral feathers rust-red, the inner webs of those nearest the central ones irregularly barred with brown; feathers of the under surface buff, those of the centre of the breast with a crescent of black at the extremity of each, which increasing in size forms a large horse-shoe-shaped patch on the centre of the abdomen; the flank feathers, in like manner, have a broad crescent of deep rusty-red at the tip of each, and a narrow line of buff down the shaft; vent, thighs, and under tail-coverts greyish-buff, without markings of any kind; bill and feet olive.

Total length, $11 \frac{1}{2}$ inches; bill, from gape, $\frac{7}{8}$; wing, $6 \frac{1}{4}$; tail, 4 ; tarsi, $1 \frac{3}{4}$.

The figures are of the natural size. 


\section{$2 \mathrm{BHL}$ Biodiversity Heritage Library}

Gould, John. 1857. "Thibet Partridge, Perdix hodgsoniae [PI. 74]." The Birds of Asia 6(IX), -. https://doi.org/10.5962/p.323427.

View This Item Online: https://www.biodiversitylibrary.org/item/122488

DOI: https://doi.org/10.5962/p.323427

Permalink: https://www.biodiversitylibrary.org/partpdf/323427

\section{Holding Institution}

Smithsonian Libraries

\section{Sponsored by}

Smithsonian Institution Libraries

\section{Copyright \& Reuse}

Copyright Status: Not in copyright

This document was created from content at the Biodiversity Heritage Library, the world's largest open access digital library for biodiversity literature and archives. Visit BHL at https://www.biodiversitylibrary.org. 